\title{
Urban resilience for transformation: Clustering of hospitality services in the Golden Horn region
}

\author{
Fatma Gözde Köseoğlu* \\ Tüzin Baycan**:(iD
}

\begin{abstract}
In this study, the clustering trend of the accommodation along with the urban renewal process in the Golden Horn region in recent years is investigated. After the districts that are mainly chosen for tourism-oriented accommodation are determined, the location selection processes of accommodation are analyzed and the reasons behind the preference of said districts are examined. The present study aims to investigate the relationship between urban policies regarding the Golden Horn region and the location selection process and to detect how the factors affecting the preference of locations regarding tourism-oriented accommodation differ in different districts. In order to deduce the factors that play an active role in the clustering process in the region, first, the distribution pattern of the accommodation activities in the two sides of the Golden Horn and the districts that are mostly preferred were determined, and then the data obtained in the field studies from semi-structured questionnaires and in-depth interviews conducted with the people representing these facilities in the determined districts, namely Balat-Ayvansaray, and Sütlüce, were interpreted. The findings of the study revealed the following original results regarding the location selection process of the tourism function in the Golden Horn: i) It was determined that there has been an increase in tourism-oriented accommodation investments in the districts in the Golden Horn region in the last 5 years; ii) The tourism-oriented accommodation facilities tend to cluster in the Golden Horn region and are predominantly located in the districts of Balat-Ayvansaray and Sütlüce; iii) Factors affecting the location selection processes of investments in two different districts differ according to the characteristics of the districts and the qualifications and preferences of the visitors. While tourism-oriented accommodation facilities are clustered in certain districts in the Golden Horn region, the reasons for clustering and the quality of the facilities that clusters vary according to the advantages of the district and the preferences of the visitors. The spatial effects caused by clustering also differ according to districts. In addition, it is observed that the location selection for accommodation in Sütlüce supports urban renewal in the district. As a result of the findings of the study, it is understood that the clustering of accommodation activity in the Golden Horn plays an important role in increasing urban resilience.
\end{abstract}

Keywords: urban resilience, urban renewal, clusters, clustering of hospitality services 


\section{Introduction}

Within the scope of a study previously carried out regarding the clustering in the Golden Horn region, the factors that are effective in the location selection processes of the cultural industries and the clustering tendencies were determined, the relationship between the cultural industries and the urban renewal process was described and the quality of the changing dynamics that drove urban renewal in the region from 2010 to 2018 were revealed (Köseoğlu and Baycan, 2020, pp. 123146). Within the scope of this study, the change in the number and nature of the cultural industries was questioned, and the way the urban transformation process developed in parallel with this change was examined.

After the establishment of the facilities, the location selection, which involves determination of the place which can provide the highest profit with the lowest cost, arises as a two-stage process, firstly selecting the region and secondly determining the land in that region (Kahraman, 1986, pp.18). In the case of the place of establishment for a tourism facility, it means a suitable area where the establishment can fulfill its basic functions such as accommodation, catering, entertainment, and its economic objectives related to these factors (Barutçugil, 1984, pp. 66-69). The place of establishment of the hotel business refers to the living space that is essential for the survival and development of the hotel business (Olalı and Korzay, 1993, pp. 96). It is possible to develop different location selection models on different issues in urban and regional planning, and there are many different models that can be applied to different functions (Arslanlı and Dökmeci, 2017, pp. 8). Factors related to location selection and financial factors are seen to be effective in the process of making investment decisions in hotels, (Newell and Seabrook, 2006, pp. 279-294).

When the location selection process of tourism facilities is analyzed from the perspective of geographical approach; urban development and urban macroform, accessibility and transportation facilities, and the physical structure of the city are observed to be the persuasive factors in the decision-making process. When the location selection process of the accommodation is reviewed within the framework of economic approach, the tendency to cluster and the externality provided by the cluster also seem to play an important role in deciding the location of the facility (Nachum, 2000 , pp. 8). The competitive advantage provided by clustering reduces the entry cost of facilities to the market (Krugman, 1991, pp. 483-499). Differentiation and diversification of the services offered, urban transformation, architectural transformation and architectural design processes influences the location decision of the facility by offering new marketing opportunities. When the renewal processes of the old British industrial cities are examined, it is seen that the socio-cultural, economic and physical elements of urban transformation play a crucial role in the decision of location selection of hotels (Bradley, Hall and Harison, 2002, pp. 61-70). Besides, congress tourism is among the services that affect the location decision of the facility by offering marketing opportunities. After World War II, hotels with meeting rooms emerged around convention centers (Law, 1993, pp. 49). On the other hand, the resources offered by public and private sector services have been effective in the location selection process of hotels (Rigal-I-Torrent and Fluvia, 2011, pp. 244-255). All these examples, which provide new marketing opportunities, require that the location selection process of these facilities be analyzed in regard to the marketing approach. Newell and Seabrook (2006, pp. 279-294) evaluated the location selection process of the accommodation within the framework of the strategic management approach and discussed the strategic management elements significant in the decision process under 5 topics: financial evaluation of the investment and evaluation in terms of location advantages, analysis of the economic situation, differentiation in the provision of services and relations with stakeholders. Plan decisions and urban policies are also included in the strategic management approach.

Yang, Luo, and Law (2014, pp. 209-220) describe four theoretical models from different disciplines: tourist-historic city model, the mono-centric model, the agglomeration model, and the multi-dimensional model. In most historic cities, the distribution of facilities is consistent with the 
tourist-historic city model, which was first defined Ashworth and Tunbridge (1990, pp. 81). In the single-center model, land is used through apartments located at a certain distance from the city center (Alonso, 1964, pp. 138). Yokeno (1968, pp. 1-36) argues that the model can be adapted to urban hotels, suggesting that hotels are located in the core of the city because visitors can afford to pay higher fees to provide easier access to the city center. Egan and Nield (2000, pp. 611-622) define the spatial hierarchy of hotels based on the distance to the city center as well. The agglomeration effect emphasized in the agglomeration model underlines the advantages that hotels provide from clustering. Drawing attention to the production and demand factors of hotel clusters, Canina, Enz, and Harrison (2005, pp. 561-585) note that due to production advantages, clustering facilitates access to resources, leading service providers, and special services. Multidimensional models, on the other hand, are developed to explain the market entry preferences of hotels with both product and geographical locations. Hotels consider geographical location as well as product position when deciding to enter the market (Baum and Haveman, 1997, pp. 304-308). The study in question shows that facilities tend to be close to existing facilities at similar wages but different size ranges.

When the factors effective in the process of deciding on the location of the accommodation facilities are examined, different factors are seen to come to the fore in different regions and for different conditions, but there are also common factors that are substantial in different decision processes. All aspects of both the city and the facility, such as developments in transportation, accessibility, land values, historical structure, environmental factors, access to public services, city macroform, hotel size, number of stars, partnership type, and variety of services are all determinants in the selection of the accommodation location (Ashworth and Tunbridge, 2011, pp. 105-135, Yang, Wong and Wang, 2012, pp. 675-685). In addition, local economic environment, plan decisions, accessibility, building height, parking area, public spaces, traffic conditions and transportation, geographical factors, natural resources, and land size are the factors that should be taken into consideration in the selection process of hotel location (Gray and Liguori, 2003, pp. 3440). Urtasun and Gutierrez (2006, pp. 282-402) try to define the location decision process by examining the properties of hotels such as geographical location, room price, room size, and services they provide. The criteria grouped under the titles of geographical location (close environment, recreational facilities), traffic conditions (accessibility, comfort), hotel characteristics (internal and external development), and operation management (human resources, operating conditions) are other elements that are emphasized in the hotel location selection process (Chou, Hsu and Chen, 2008, pp. 293-301). The market demand and the number of incoming tourists, tourist expenditures, current foreign direct investment, the business environment depending on the gross national product per capita, and tourism policies are indicated to have significant effects on the decision of multinational companies for hotel location (Zhang, Guillet, and Gao, 2012, pp. 350-359). In short, various elements such as the factors related to the city, the region and the facility itself, urban policies and plan decisions, national policies, the economic conditions of the country, and the quality and quantity of visitors are determinants in the location selection decisions of accommodation facilities.

Considering the regions where accommodation facilities are located in Istanbul, it is seen that they are mostly present in Fatih, Beyoğlu and Şişli districts. According to the Istanbul Metropolitan Municipality's 2020 Accommodation Facilities Inventory Report, there are 2,878 accommodation facilities in Istanbul, including 637 with a tourism business certificate and 2,241 with a license certificate obtained from the municipalities. When the distribution of tourism facilities throughout Istanbul by districts is examined, Fatih district is seen to contain a total of 1,284 accommodation facilities, including 218 with a tourism business certificate and 1,066 with a license certificate obtained from the municipality. Fatih district is followed by Beyoğlu district with 353 accommodation facilities, including 127 with a tourism business certificate and 226 with a license certificate obtained from the municipality. A total of 206 accommodation facilities, 67 of which have a tourism business certificate and 139 of which have a municipal license certificate, are located 
in Şişli district. In Beşiktaş district, there are a total of 201 accommodation facilities, including 127 with a tourism business certificate and 74 with a license certificate obtained from the municipality. ${ }^{1}$

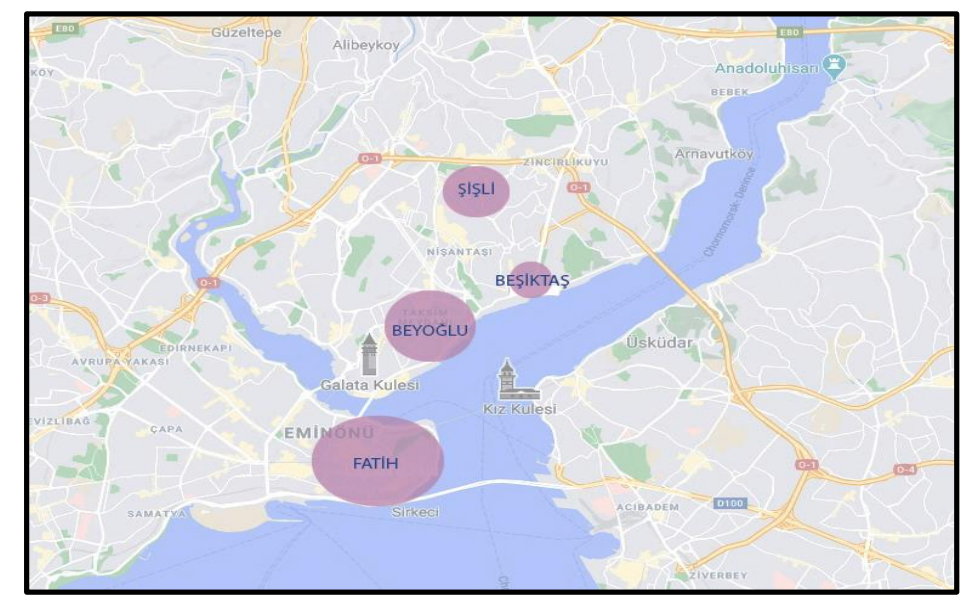

Figure 1 Regions where accommodation activities are clustered in Istanbul

Istanbul, which embodies a unique cultural accumulation thanks to her being the capital of different civilizations throughout history and being the metropolis where the economic and social activities of a developing country are concentrated, is a very important tourism city for Turkey. The Grand Bazaar, The Hagia Sophia Museum, The Topkapı Palace and Museum, The Dolmabahçe Palace and Museum, The Yıldız Palace, and The Basilica Cistern are the most significant centers of attraction. In addition to tourists traveling for cultural and entertainment purposes, tourists who travel for companies are also interested in the city, and a large number of domestic and foreign tourists visit the city for business purposes. Levent and Maslak regions are financial centers housing the headquarters of Turkey's major companies and banks.

Within the scope of this study, the relationship between urban policies regarding the Golden Horn region and the location selection process is examined, the districts that the tourism-oriented accommodation facilities choose predominantly in the Golden Horn are determined and how the factors that affect the location selection process of the tourism-oriented accommodation in the region differ in various districts according to the visitors and the characteristics of the region are analyzed. In addition, the reasons for choosing the Golden Horn instead of other clustering areas such as Taksim and Sultanahmet are discussed and the relationship between the clustering of tourism-oriented accommodation and urban renewal is questioned. In the second part of the study, the Istanbul Environmental Plan 1/100.000 and the urban policies for tourism envisaged in it are discussed. Besides, the importance of the Golden Horn region in regard to the tourism projects of the plan is explained, and creation of favorable conditions for tourism investments in the Golden Horn region through urban policies is underlined. In the following section, based on the results of the field study, the districts where accommodation facilities are concentrated within the Golden Horn area are determined by investigating the increase in the number of tourism facilities in the region in recent years. Then, the factors affecting the location selection of the accommodation in Sütlüce and Balat-Ayvansaray districts, which are the regions where the accommodation is clustered, are discussed and how those factors differ according to the districts in question are examined. In addition, the relationship between tourism accommodation and urban renewal is evaluated regarding Sütlüce and Balat areas. Finally, the findings related to the clustering of accommodation facilities in the Golden Horn and the location selection process of those facilities are assessed. 
2. Urban Policies for the Golden Horn Region and Tourism in the Istanbul Environmental Plan $1 / 100.000$

It is specified in the Istanbul Environmental Plan 1/100.000 that the aim of the plan is to "make Istanbul a stronger city on a global scale". Within the scope of the plan that was approved in 2009, cultural and touristic elements are given prominence for the objective of presenting Istanbul as a strengthened city globally.

The Historical Peninsula, Haliç, Beyoğlu, Kadıköy, and Üsküdar regions, which encompass historical and cultural values and a high tourism potential, are envisaged as culture-oriented tourism areas in the plan. Supporting the use of industrial heritage buildings for cultural purposes and evaluating the Golden Horn as a cultural axis in this context are among the other objectives of the plan.

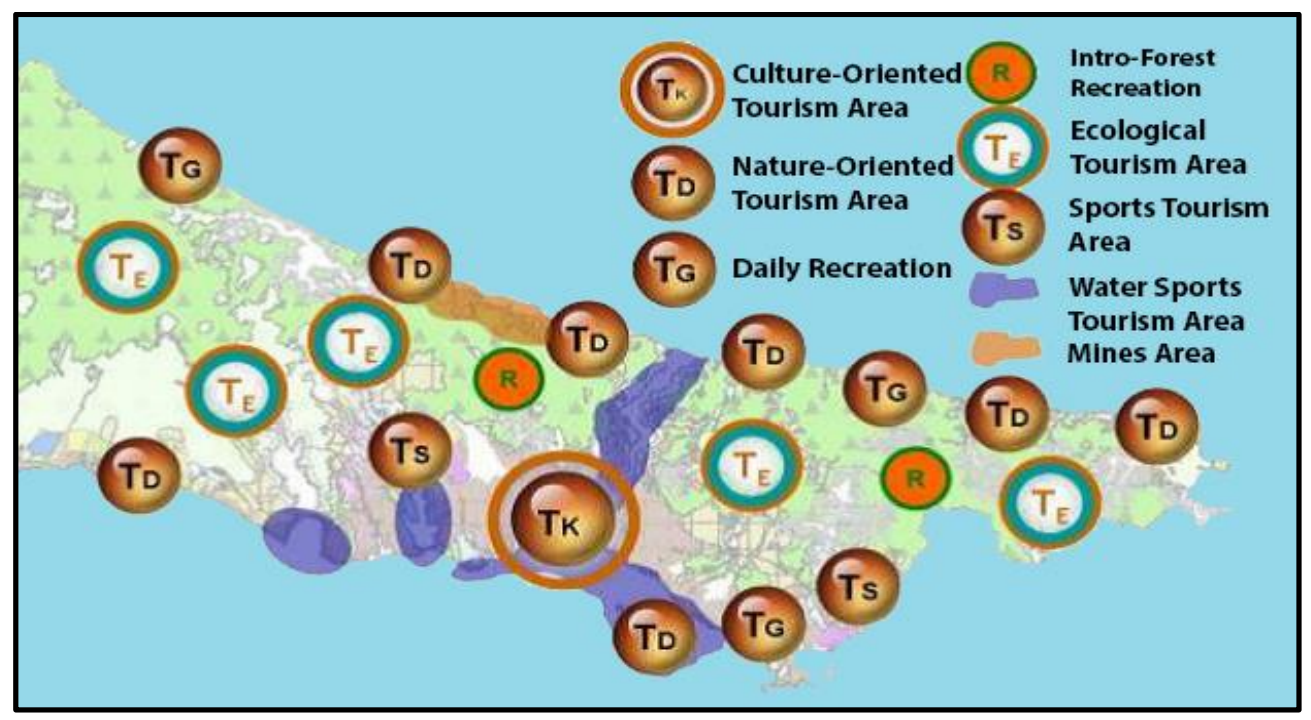

Figure 2 Urban policies developed for tourism In Istanbul Environmental Plan 1/100.000 (Istanbul Environmental Plan Report)

It is emphasized in Istanbul Environmental Plan 1/100.000 that the historical-cultural texture, landscape, and silhouette of the Golden Horn region, which makes a significant contribution to the identity of the city will be preserved in order to support cultural tourism in the historical peninsula and Beyoğlu, and the "Golden Horn cultural axis" will be highlighted to integrate it with the historical peninsula and Beyoğlu. In this context, the purpose is to ensure the continuity of pedestrian and green areas along the Golden Horn shore, which are defined as the green axes of the city, and to create public parks and recreation areas, museums, and congress areas for coastal use.

The plan notes also state that "culture industries" based on ideas and design are aimed to be established in the sectoral structure of Istanbul and that in accordance with the environmental texture, food and beverage, entertainment, cultural activities, shopping units, small scale manufacturing workshops for tourism, and trade and service functions such as handicrafts and cultural industries can be organized in the culture-oriented tourism areas.

In brief, it can be inferred from the plan that appropriate conditions are created for tourism investments in the Golden Horn region through urban policies. 
3. Comparison of the Clustering Tendency of the Accommodation Facilities in the Golden Horn Region, The Factors Affecting the Location Selection Process, And the Spatial Effects of The Clustering

The field study was conducted in the Golden Horn region and in-depth interviews were conducted with competent people representing accommodation facilities, guided by semistructured surveys. Then, the data obtained were interpreted (Table 1). As part of the interviews, participants were asked questions about the accommodation facility, location selection process and clustering, and about their visitor profile.

Table 1 Businesses interviewed in Golden Horn

\begin{tabular}{|l|l|}
\hline Facility Name & Operation Year \\
\hline Clarion Hotel Golden Horn & 2017 \\
\hline Ramada Hotel Golden Horn & 2016 \\
\hline Hilton Garden Inn & 2014 \\
\hline Terrace Suits Apartments & 2017 \\
\hline Lazzoni Hotel & 2015 \\
\hline Fanaraki Aparts & 2016 \\
\hline Balat Residence & 2016 \\
\hline Polat Suits & 2015 \\
\hline Palation House Apart & 2017 \\
\hline Akın House Apart & 2015 \\
\hline Sultan Suites & 2016 \\
\hline Sur Konak & 2016 \\
\hline Millennium Istanbul Golden Horn & 2018 \\
\hline The Anemas Inn & 2019 \\
\hline Lotus Hotel & 2015 \\
\hline Troya Otel & 2015 - Transfer Date \\
\hline Mövenpick Hotel Istanbul & 2017 \\
\hline The Elegant Hotel & 2017 \\
\hline Turquhouse Boutique Hotel & 1999 \\
\hline Ihva Otel & 2018 \\
\hline
\end{tabular}

It was discovered within the scope of the study that one of the accommodation facilities identified and reached in the Golden Horn region began operating in 1999, whereas the rest began their operations between 2014 and 2019 (Table 1). When the field study data is examined, an increase has been observed in tourism-oriented accommodation investments in the districts of the Golden Horn region in the last 5 years.

3.1. The Tendency of Accommodation Facilities to Cluster in The Golden Horn Region and Differentiation in The Nature of The Facilities According to The Districts

Within the framework of the investigations carried out in the Golden Horn region in 2010, the first objective was to determine the regions where the accommodation facilities were clustered and their years of operation. Of the 20 accommodation facilities identified in the Golden Horn region, 11 are located around Balat-Ayvansaray, 5 are located in Sütlüce, and the others are located in Pier Loti, Eyüp and Silahtarağa. In other words, the tourism-oriented accommodation activities in the Golden Horn are observed to cluster in Balat-Ayvansaray and Sütlüce (Table 2).

Table 2 Factors affecting location selection of accommodation facilities

\begin{tabular}{|c|l|l|}
\hline Facility Name & Location & Operation Year \\
\hline Clarion Hotel Golden Horn & Sütlüce & 2017 \\
\hline Ramada Hotel Golden Horn & Sütlüce & 2016 \\
\hline
\end{tabular}




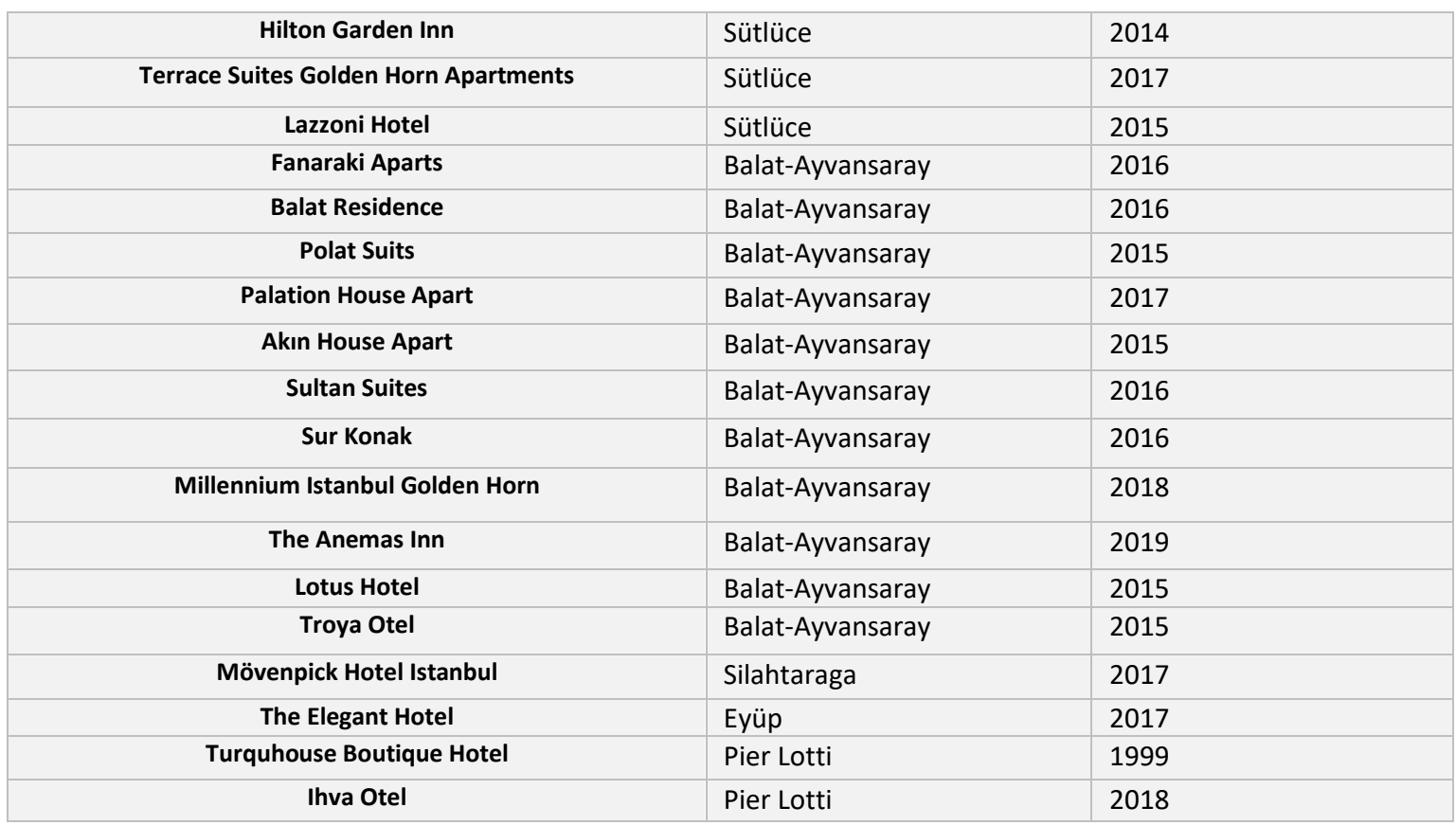

Considering the years when the accommodation facilities located in Balat and Ayvansaray were established, 4 of them started operating in 2015, 4 of them in 2016, one of them in 2017, one of them in 2018 and one of them in 2019. Of the 5 accommodation facilities in Sütlüce, one of them started its operations in 2014, one in 2015, one in 2016, and the other two in 2017. An analysis of the data obtained reveals that there are 2 facilities in Silahtarağa and Eyüp that started operating in 2017 and 2 facilities in Pier Loti that started in 1999 and 2017 (Table 2).

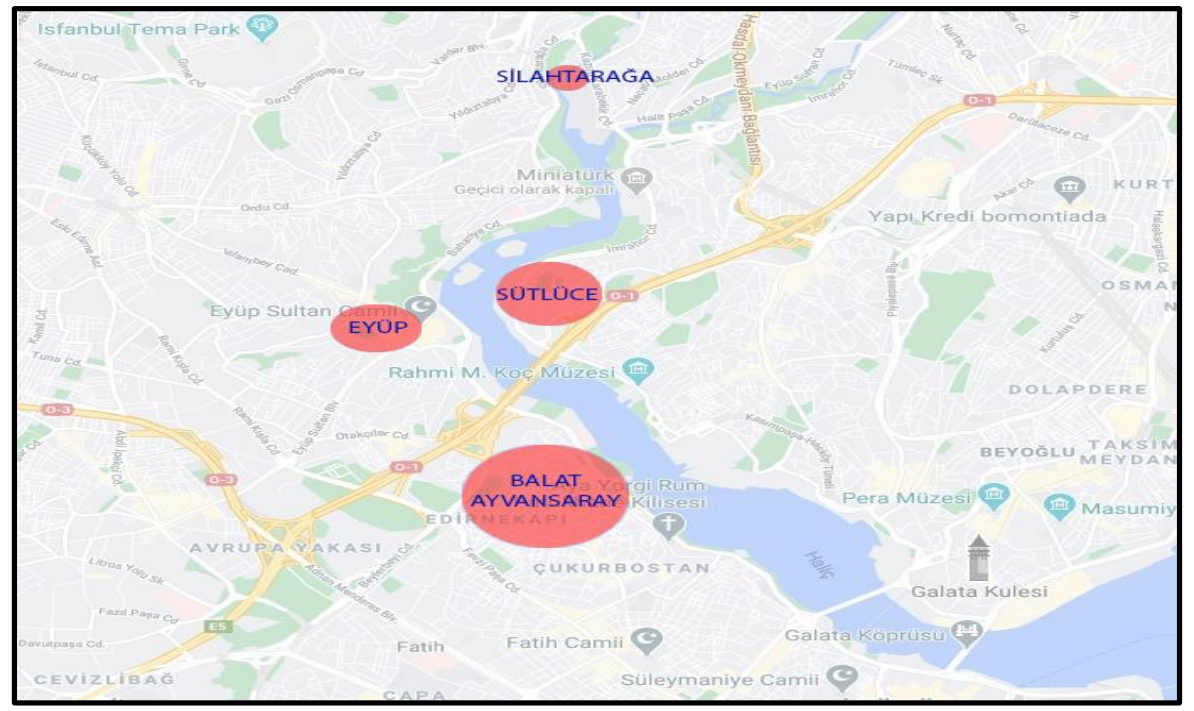

Figure 3 Areas where accommodation facilities are clustered in Golden Horn

Considering the years when the facilities began their operations, as mentioned earlier, almost all of them have been found to have begun operating in the last 5 years.

When the facilities located around Balat-Ayvansaray and the accommodation facilities located in Sütlüce are compared, the facilities differ in size and quality according to the districts. Data obtained from in-depth interviews conducted in Sütlüce reveal that the facilities located in the district are 3, 4, and 5-star hotels. The number of beds in the aforesaid facilities in Sütlüce varies between 139 and 420, and the occupancy rates vary between $70 \%$ and $80 \%$. In addition, the accommodation facilities located in Sütlüce have at least 1 meeting room: Hilton Garden Inn has 7 meeting rooms and Lazzoni Hotel has 5 meeting rooms. 
Table 3 Comparison of facilities located around Balat and Sütlüce

\begin{tabular}{|c|c|c|c|c|c|}
\hline Name of Facility & Location & Type of Facility & $\begin{array}{l}\text { Meeting } \\
\text { Room }\end{array}$ & $\begin{array}{l}\text { Number } \\
\text { of Beds }\end{array}$ & Occupancy Rate (\%) \\
\hline Clarion Hotel Golden Horn & Sütlüce & 4-Star Hotel & Yes & 390 & $75-80$ \\
\hline Ramada Hotel Golden Horn & Sütlüce & 4-Star Hotel & Yes & 220 & $70-80$ \\
\hline Hilton Garden Inn & Sütlüce & 4,5-Star Hotel & Yes (7 in total) & 420 & 75 \\
\hline $\begin{array}{l}\text { Terrace Suites Golden Horn } \\
\text { Apartments }\end{array}$ & Sütlüce & 3-Star Hotel & No & 139 & 75 \\
\hline Lazzoni Hotel & Sütlüce & 5-Star Hotel & Yes (5 in total) & 262 & 78 \\
\hline Fanaraki Aparts & Balat-Ayvansaray & $\begin{array}{l}\text { Apart-Hotels } \\
\text { to Rent Daily/Weekly/Monthly }\end{array}$ & No & 6 & Unknown \\
\hline Balat Residence & Balat-Ayvansaray & $\begin{array}{c}\text { Apart-Hotels } \\
\text { to Rent Daily/Weekly/Monthly }\end{array}$ & No & 6 & Unknown \\
\hline Polat Suits & Balat-Ayvansaray & $\begin{array}{c}\text { Apart-Hotels } \\
\text { to Rent Daily/Weekly/Monthly }\end{array}$ & No & 6 & Unknown \\
\hline Palation House Apart & Balat-Ayvansaray & $\begin{array}{c}\text { Apart-Hotels } \\
\text { to Rent Daily/Weekly/Monthly }\end{array}$ & No & 6 & Unknown \\
\hline Akın House Apart & Balat-Ayvansaray & $\begin{array}{c}\text { Apart-Hotels } \\
\text { to Rent Daily/Weekly/Monthly }\end{array}$ & No & 5 & Unknown \\
\hline Sultan Suites & Balat-Ayvansaray & $\begin{array}{c}\text { Apart-Hotels } \\
\text { to Rent Daily/Weekly/Monthly }\end{array}$ & No & 7 & Unknown \\
\hline Sur Konak & Balat-Ayvansaray & $\begin{array}{c}\text { Apart-Hotels } \\
\text { to Rent Daily/Weekly/Monthly }\end{array}$ & No & 6 & Unknown \\
\hline Millennium Istanbul Golden Horn & Balat-Ayvansaray & 5-Star Hotel & Yes & 254 & 70 \\
\hline The Anemas Inn & Balat-Ayvansaray & Boutique Hotel & No & 21 & 50 \\
\hline Lotus Hotel & Balat-Ayvansaray & Hostel & No & 18 & 80 \\
\hline Troya Otel & Balat-Ayvansaray & Boutique Hotel & No & 30 & 60 \\
\hline
\end{tabular}

Accommodation facilities located around Balat and Ayvansaray differ from the facilities located in Sütlüce in both size and quality. The field study conducted reveals that the 5-star Millennium Istanbul Golden Horn located in Ayvansaray has a capacity of 254 beds and a meeting room, and its occupancy rate is $70 \%$. However all other accommodation facilities located around Balat and Ayvansaray are apart-hotels rented for daily, weekly or monthly periods. These facilities, called apart-hotels, are 6-7 room buildings formed by the renovation of traditional architectures, and although you can communicate with the representatives of these facilities on the internet pages, the fact that they are accommodation facilities is not obvious when you walk around the district and look at the buildings from the outside. In other words, the apartments in question operate informally.

Data obtained from in-depth interviews conducted around Balat-Ayvansaray and in Sütlüce indicate that the accommodation facilities in the regions located on two different sides of the Golden Horn differ in size and quality.

\subsection{Comparison of Factors Affecting the Location Selection Process of Accommodation Facilities by District}

The field study conducted in Sütlüce and Balat-Ayvansaray districts, which are the areas where accommodation facilities are clustered in the Golden Horn region, reveals that the factors affecting the location selection process of the investments differ according to both the characteristics of the districts and the expectations and qualifications of the visitors.

\subsubsection{Differentiation of Factors Affecting Location Selection According to Visitors' Expectations and Preferences}

In addition to the size and quality of the accommodation facilities located in Balat-Ayvansaray and Sütlüce, the visitor profile also varies between the two districts. 
Table 4 Comparison of visitor profile of facilities located around Balat and Sütlüce

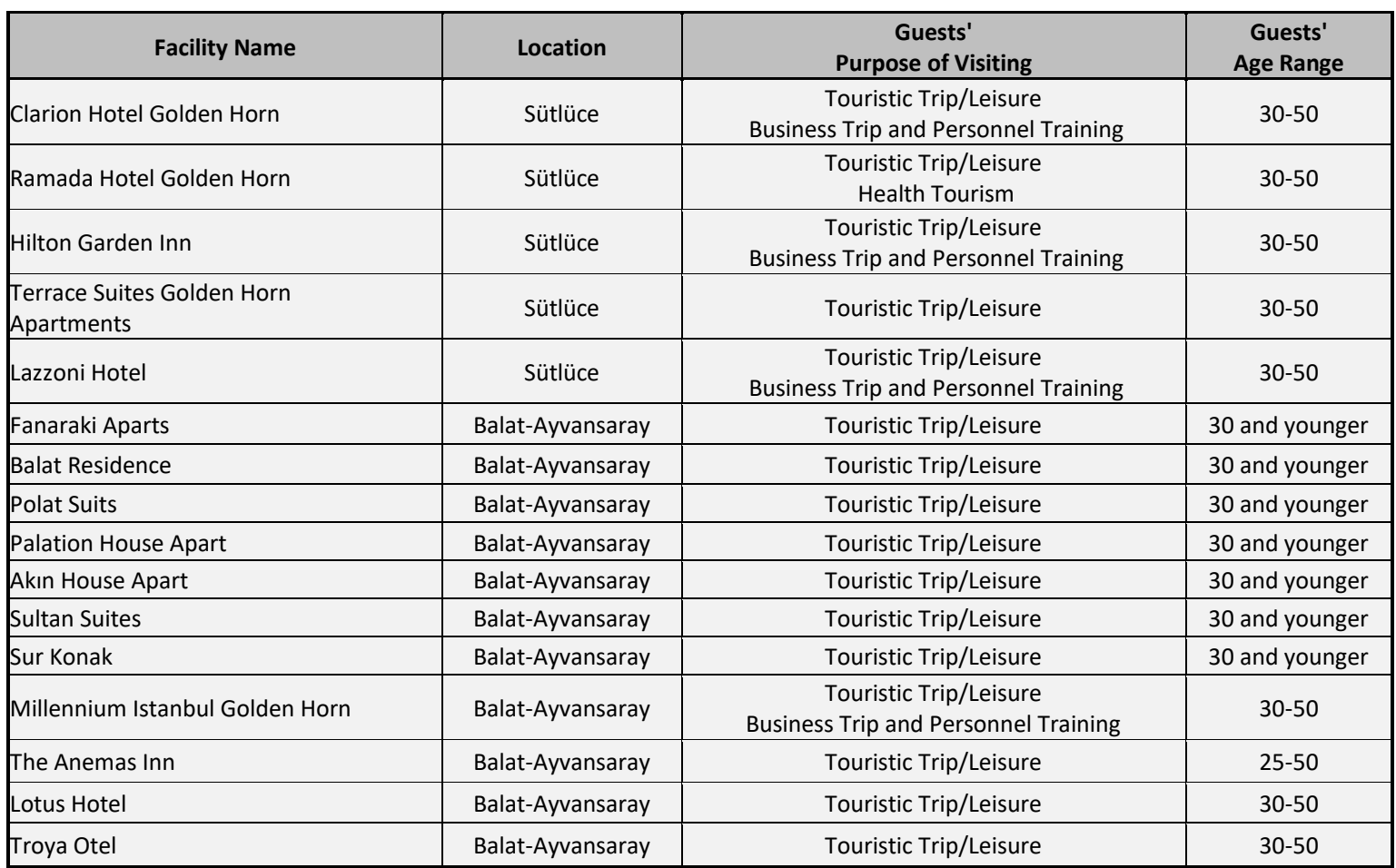

The surveys conducted with the representatives of the facilities in Sütlüce reveal that all the visitors of the accommodation facilities in the district are aged between 30 and 50 years old. In Balat, on the other hand, the age range of the visitors varies according to the type of facility. It is seen that all those staying in the apartments are 30 years old or younger, while those who stay in the hotels are aged between 25 and 50 .

Similarly, the reason for the visit differs between the two districts, as does the age range of visitors. Visitors to Sütlüce seem to stay there for business trips and personnel training as well as leisure, whereas visitors to Balat travel for purposes of touristic trips and leisure.

When the survey results are assessed together, it can be suggested that the accommodation facilities in the two different sides of the Golden Horn have been shaped considering the needs and expectations of the visitors of the districts where they are located. In other words, the factors affecting the location selection processes of the accommodation investments in two different districts vary according to the characteristics and preferences of visitors.

\subsubsection{Differentiation of Factors Affecting Location Selection According to The Characteristics of Districts}

The purpose in the interviews carried out in the Golden Horn region was to determine the factors that were effective in the selection of accommodation facilities around Sütlüce and BalatAyvansaray. Hence, as part of the field study conducted, representatives of the facilities were asked to rate the factors that were effective in the location selection processes in the region between 1 and 5 according to their importance.

After the scorings of the facility representatives interviewed in Sütlüce were evaluated, it was observed that the "land development and investment opportunities" factor stood out with 25 points. "Transportation opportunities", which fetched a total of 22 points, was the second factor significant in the location selection process of the facilities, while the factors "proximity to other tourism investments" and "urban renewal", which received 21 points each, shared the third place (Table 5). During the interviews, the participants indicated tranquility, serenity, and the natural 
environment as the other crucial factors that were effective in the selection of locations for the facility representatives.

Table 5 Factors affecting location selection of facilities in Sütlüce

\begin{tabular}{|c|c|}
\hline $\begin{array}{c}\text { Factors affecting location selection of facilities } \\
\text { in Sütlüce }\end{array}$ & Point \\
\hline Urban Renewal Process & 21 \\
\hline Transportation Opportunities & 22 \\
\hline Proximity to The City Center & 19 \\
\hline Historical Texture & 18 \\
\hline Proximity to Other Tourism Investments & 21 \\
\hline Building Quality & 19 \\
\hline Social Diversity & 19 \\
\hline Land Development and Investment Opportunities & 25 \\
\hline
\end{tabular}

The evaluation of the ratings of the representatives of the accommodation facilities interviewed around Balat revealed that the "land development and investment opportunities" factor ranked first, collecting 54 points. "Historical texture", which received a score of 32, was the second factor that was effective in the location selection process of the facilities. However, the significance of the sizeable difference in score between the first and second factors should be underlined. The "urban renewal process" factor, which collected a total of 22 points, was found to be the third active factor in the location selection process of the facilities as a result of the evaluation (Table 6).

Table 6 Factors affecting location selection of facilities in and around Balat

\begin{tabular}{|c|c|}
\hline $\begin{array}{c}\text { Factors affecting location selection of facilities } \\
\text { in and around Balat }\end{array}$ & Point \\
\hline Urban Renewal Process & 22 \\
\hline Transportation & 13 \\
\hline Proximity To The City Center & 10 \\
\hline Historical Texture & 32 \\
\hline Proximity To Other Tourism Investments & 5 \\
\hline Building Quality & 11 \\
\hline Social Diversity & 14 \\
\hline Land Development and Investment Opportunities & 54 \\
\hline
\end{tabular}

It is noteworthy that the factor expressed by the facility representatives as a priority in both districts is the "land development and investment opportunities". Moreover, the factor in question ranks first by far, according to the results of the field study data conducted around Balat, and there is a substantial score difference between that factor and the following effective factor. However, it was determined in in-depth interviews that this factor had a different significance for the districts located on two different sides of the Golden Horn. "Land development and investment opportunities" factor, which ranked first in Sütlüce, means that there are empty land plots in the region and there is no property problem, while the same factor in and around Balat indicates utilizing the current demand to evaluate the existing buildings. Hotel investors will prefer land development in a region where many elements such as proximity to the city center, transportation opportunities, historical texture, and natural environment coexist. Sütlüce, in addition to possessing the said factors, offers investors a very important advantage for development with its investment-friendly land plots. For apart-hotel investments located around Balat-Ayvansaray, the investment opportunity suggests a different meaning. Along with the demand for visitors caused by the historical and traditional texture of the region, the presence of empty buildings that have been started to be renovated but are not used resulted in many residences turning into flexible facilities that can be rented daily, weekly, or monthly and gaining accommodation function.

When the factors affecting the location decision of the accommodation facilities in Sütlüce and Balat-Ayvansaray are classified in accordance with the approaches to the location selection process, 
the "land development and investment opportunities" factor falls into the strategic management approach. Similarly, plan decisions and urban policies and public and private sector services are included in this approach. Clustering of accommodation facilities in the districts is a factor envisaged by the economic approach in the location selection process. When we assess the location selection process in Sütlüce from the marketing approach, it is observed that congress tourism, urban renewal, the transformation of industrial buildings and public investments are among the factors that attract facilities to the district. Likewise, physical renewal and restorations and urban renewal are effective in selection of the location of accommodation facilities in and around Balat. Considering the factors that are effective in location selection within the framework of geographical approach, urban development and urban macroform, accessibility and transportation and natural environment factors influence the location selection of accommodation facilities on both sides of the Golden Horn. The potency of the historical-traditional texture and identity factor in the process of starting up accommodation facilities in and around Balat should also be emphasized. Nevertheless, the most substantial reason for the facilities to choose the Golden Horn instead of clustering areas such as Taksim and Sultanahmet was found to be the advantage of unique land development and investment opportunities offered by the districts.

Therefore, the factors affecting the location selection processes of the investments in two different districts differ not only according to the characteristics of the visitors as described earlier but also according to the characteristics of the districts. The fact that both districts offer unique investment opportunities for investors is the determining factor in the selection of the Golden Horn instead of the clustering areas such as Taksim and Sultanahmet.

\subsection{Comparison of The Relationship Between Clustering and Urban Renewal by District}

As part of the field study conducted around Sütlüce and Balat-Ayvansaray, the participants representing the accommodation facilities were asked about the development method of the property belonging to the facility and the previous purpose of use of the property in order to question the spatial effects of the location selection of the accommodation facilities.

Table 7 Development method of property in Sütlüce

\begin{tabular}{|c|c|}
\hline Sütlüce- How was the property developed? & Point \\
\hline By redevelopment & 5 \\
\hline
\end{tabular}

In-depth interviews conducted in Sütlüce show that the accommodation facilities in the district are implemented on plot lands with vacant or idle buildings and by the method of redevelopment of real estate (Table 7-8).

Table 8 Earlier use of property in Sütlüce

\begin{tabular}{|c|c|}
\hline Sütlüce- What was the purpose of the use of the property before obtaining the accommodation function? & Point \\
\hline Vacant Land Plot & 3 \\
\hline Idle building & 2 \\
\hline
\end{tabular}

The location selection of the accommodation facilities in Sütlüce resulted in vacant plots and unused, idle buildings turning into 3, 4, and 5-star hotels. The co-interpretation of the field study data indicates that the clustering of the accommodation facilities in Sütlüce leads to physical renewal and the revival of socio-economic life. 


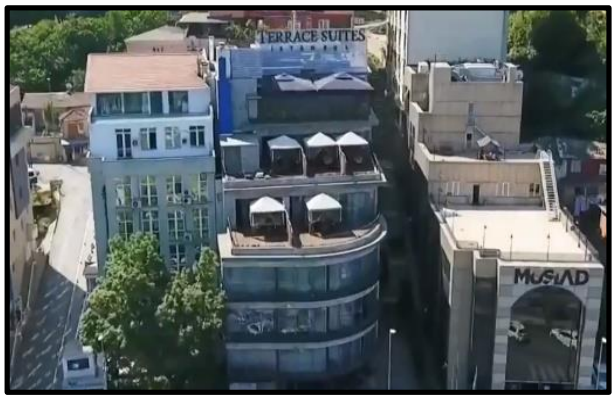

Figure 4 Terrace Suites Golden Horn (URL 1)

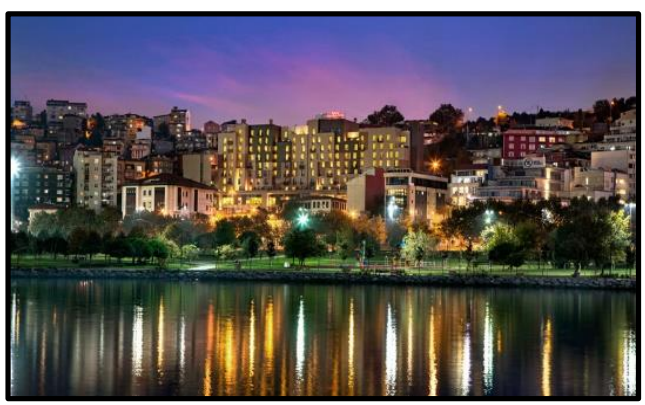

Figure 6 Hilton Garden Inn (URL 3)

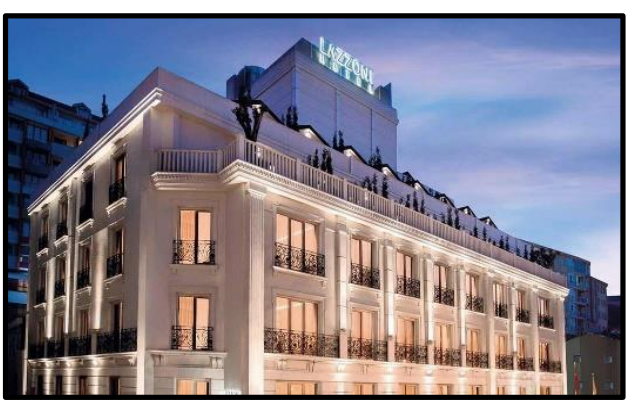

Figure 5 Lazzoni Hotel (URL 2)

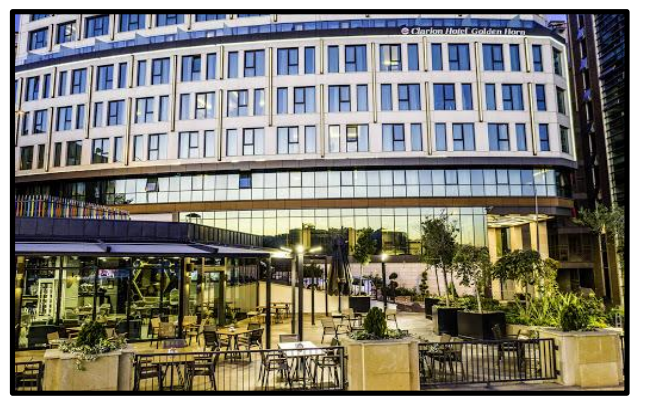

Figure 7 Clarion Hotel (URL 4)

Interviews conducted in and around Balat indicate that the structures in Fener, Balat, and Ayvansaray have been renovated with repair and restoration and that these structures have gained accommodation function in the following process (Table 9-10).

Table 9 Development method of property in Balat-Ayvansaray

\begin{tabular}{|c|c|}
\hline Balat-Ayvansaray- How was the property developed? & Point \\
\hline Restoration & 9 \\
\hline Renovation & 2 \\
\hline
\end{tabular}

The field study pointed out that all accommodation facilities in Balat underwent restoration or repair, and all apartments were residential before they gained the function of accommodation. Afterwards, the restoration and renovation dates of the buildings with accommodation functions were compared with the dates when they started operating (Table 11). This comparison showed that the buildings acquired an accommodation function much later than they were restored, which indicates no significant relationship between the accommodation function and physical renewal.

Table 10 Earlier use of property in Balat-Ayvansaray

\begin{tabular}{|c|c|}
\hline Balat-Ayvansaray - What was the purpose of the use of the property before obtaining the accommodation function? & Point \\
\hline Restored residence & 7 \\
\hline Old building & 3 \\
\hline Not known & 1 \\
\hline
\end{tabular}

When the restoration or renovation dates of the apart-hotels that make up the majority of the facilities are compared with their operation dates, it transpires that the effect of clustering on urban renewal is much less than that in Sütlüce and that one cannot talk of an effect similar to the one in Sütlüce for the apart-hotels located in the Balat-Ayvansaray region (Table 11). 
Table 11 Renovation dates of the real estates in Balat-Ayvansaray

\begin{tabular}{|l|l|c|c|}
\hline \multicolumn{1}{|c|}{ Facility Name } & Location & $\begin{array}{c}\text { Operation } \\
\text { Year }\end{array}$ & Restoration or Renovation Year \\
\hline Fanaraki Aparts & Balat-Ayvansaray & 2016 & 2006 \\
\hline Balat Residence & Balat-Ayvansaray & 2016 & 2008 \\
\hline Polat Suits & Balat-Ayvansaray & 2015 & 2010 \\
\hline Palation House Apart & Balat-Ayvansaray & 2017 & 2013 \\
\hline Akın House Apart & Balat-Ayvansaray & 2015 & 2013 \\
\hline Sultan Suites & Balat-Ayvansaray & 2016 & 2010 \\
\hline Sur Konak & Balat-Ayvansaray & 2016 & 2009 \\
\hline Millenium Golden Horn & Balat-Ayvansaray & 2018 & 2018 \\
\hline The Anemas Inn & Balat-Ayvansaray & 2019 & 2018 \\
\hline Lotus Hotel & Balat-Ayvansaray & 2015 & 2015 \\
\hline Troya Otel & Balat-Ayvansaray & $2015-$ Transfer Date & 2000 \\
\hline
\end{tabular}

Hence, it can be concluded the accommodation cluster in Sütlüce results in physical renewal and revitalization of socio-economic life, while the location selection for accommodation activities in the Balat-Ayvansaray district does not have a significant impact on physical and urban renewal.

\section{Results and Evaluation}

The first finding of the field study is an increase in the tourism-oriented accommodation investments in the districts located in the Golden Horn region in the last 5 years. The results of the field study also show that the tourism-oriented accommodation facilities tend to cluster in the Golden Horn region and mainly prefer locations in Balat and Ayvansaray and Sütlüce districts.

Besides, the accommodation facilities in these cluster areas located on both sides of the Golden Horn differ from each other in size and quality. Facilities that tend to cluster in Sütlüce consist of hotels with 3, 4 and 5 stars that have at least 1 meeting room, beds varying in number between 139 and 420 , and an occupancy rate between 70 and $80 \%$. On the other hand, the accommodation facilities in the Balat-Ayvansaray district are apart-hotels with 6-7 rooms, which are rented daily, weekly or monthly, and were formerly used as residences. It has been observed that although representatives of these apart-hotels could be contacted via their internet pages, they operate informally and they do not not look like accommodation facilities when viewed from the outside.

The study reveals that not only the facilities, but also the factors affecting the location selection decision of the facilities differ for the two different regions. Within the scope of the study, the contrast in the factors affecting the location selection of the accommodation in Balat-Ayvansaray and Sütlüce has been discussed under two headings: the qualities of the districts and the expectations and preferences of the visitors. The interviews with representatives of the facilities in Sütlüce reveal that all visitors of the accommodation facilities located in the district are aged between 30 and 50, and that they stay for business trips and personnel training in addition to leisure. By contrast, all the visitors staying in apartments in the Balat-Ayvansaray district are people aged 30 and younger who travel for purposes of touristic trips and leisure. Location selection processes, such as the qualifications of accommodation investments in two different regions, are shaped according to the qualifications and preferences of their visitors.

On the other hand, it was found that the factors affecting the location selection of the accommodation facilities in the Sütlüce and Balat-Ayvansaray districts differ according to the different qualities of the districts. Some of the qualities of the Sütlüce and Balat-Ayvansaray districts were decisive in the selection process of the accommodation facilities. It was discovered that the factors of "land development and investment opportunities", "transportation opportunities and proximity to other tourism investments", and "urban renewal process" were effective, in the location selection process of the facilities in Sütlüce. As for Balat, the factors of "land development 
and investment opportunities", "historical texture" and "urban renewal process" were the factors that were crucial in the decision. However, the field study has made it clear that the "land development and investment opportunities" factor differs in meaning for the districts located on the two banks of the Golden Horn. While the "land development and investment opportunities" factor in Sütlüce offers the advantages of having empty land plots in the region and preventing possible property issues, it means taking advantage of the current demand to evaluate the buildings in and around Balat. Hotel investors will seek land development in a region where many factors such as proximity to the city center, transportation possibilities, historical texture and natural environment coexist. In addition to all these qualities, Sütlüce offers investors a very important development advantage with its investment-friendly vacant and property-free land plots. The investment opportunity carries a different meaning for the apart-hotels located around BalatAyvansaray. During the renovation process, renovated or restored but unused and vacant residences have become flexible facilities that can be rented daily, weekly or monthly as a result of the investment opportunity offered by meeting the intense visitor demand caused by the historical and traditional texture of the region with the existing renovated building stock. The advantages offered by land development and investment opportunities also explain the reasons why accommodation facilities choose Haliç instead of clustering areas such as Taksim and Sultanahmet.

In the efforts to integrate the Golden Horn region into the Historical Peninsula and Beyoğlu, the emphasis on preserving its historical-cultural texture, landscape, and silhouette and turning it into a cultural axis in the upper-scale plan has undoubtedly been another factor in the orientation of the tourism accommodation concentrated in the Historical Peninsula and Beyoğlu to the Golden Horn. This emphasis in the plan refers to the impact of urban policies throughout the city and the orientation of the tourism function to the Golden Horn region. It also underscores the relationship between urban policies and the location selection process of the tourism-oriented accommodation. However, accommodation investments, which have increased in the districts located in the Golden Horn region over the past 5 years, have shown a tendency to cluster and have mainly dominated the districts of Balat-Ayvansaray and Sütlüce. At this point, the location selection process of the tourism-oriented accommodation gains significance to explain the cluster. Tourism accommodation facilities are clustered in Sütlüce and Balat-Ayvansaray districts, but the factors affecting the location selection processes of the tourism accommodation in these districts differ both according to the characteristics of the districts and the qualities of the visitors. In both districts, the investment opportunity plays the most effective role in the location selection process, but it does so in a different way. While the absence of property problems and the existence of investmentfriendly land plots is decisive in Sütlüce, the goal of the initiatives in Balat is to benefit from the current demand to evaluate their existing properties in the most profitable way. The fact that the "land development and investment opportunities" factor is the most effective element in the site selection process of facilities has made it necessary to analyze it in terms of the strategic management approach. In addition to the strategic management approach, when the economic, marketing, and geographical aspects are considered, it transpires that many different factors are effective in the location selection in Sütlüce and Balat-Ayvansaray.

The study also suggests that the contribution of the location selection decision and clustering of the accommodation facilities to the renewal process differs in the two districts. The selection of Sütlüce for tourism investments has reconstructed the district physically and socio-economically, when the restoration and renovation dates of the apart-hotels, which constitute the majority of the facilities, are compared with their operational years. On the other hand, the effect of accommodation on urban renewal is relatively less in Balat, and it has almost no contribution, especially to physical renewal.

When the data obtained before the field study and the findings of the field study were evaluated together, it was observed that the accommodation opportunities offered by the Golden Horn region helped reduce the pressure the tourism sector creates on Historic Peninsula and Beyoğlu 
Regions, where tourism potential is high- in other words, the resilience of the Golden Horn region was tested within the scope of the study. In the previous stages of the study, the purpose of the study was stated as creation of favorable conditions for tourism investments in the Golden Horn region through urban policies; therefore, it was envisaged that the facilities that would serve the tourism sector in line with the texture in which it is located in the region. The findings of the field study conducted in the region indicate that the Sütlüce and Balat-Ayvansaray districts, which are located on the opposite banks of the Golden Horn, create appealing conditions for the location selection of the tourism accommodation facilities through their unique qualities and their own dynamics. Briefly, with the unique identity, historical texture, cultural heritage, and authentic atmosphere of the Golden Horn, accommodation facilities tend to cluster in the Golden Horn region as a result of the advantages offered by investment opportunities that are prominent Sütlüce and Balat-Ayvansaray districts. While the Golden Horn region is functionally integrated with the Historical Peninsula and Beyoğlu, it also proves its resilience by sharing the pressure that accommodation activity creates on these regions.

\section{References}

Alonso, W. (1964). Location and Land Use. Cambridge: Harvard University Press.

Arslanlı, K. and Dökmeci, V. (2017). Arazi Kullanım ve Yer Seçimi Modelleri. Dökmeci, V. and Türk, Ş.Ş. (Ed), In Yer Seçimi Kuramı ve Uygulamaları. (8-28). İstanbul: SEBA Yayıncılık.

Ashworth, G. J. and Tunbridge, J. E. (2011). The Tourist-historic City: Retrospect and Prospect of Managing the Heritage City. London and Newyork: Routledge.

Bradley, A. and Hall, T., Harrison, M. (2002). Selling Cities: Promoting New Images for Meetings Tourism. Cities, 19 (1), 61-70.

Barutçugil, í. S. (1984). Turizm Iş̧letmeciliği (2 ${ }^{\text {nd }}$ ed.). Bursa: Uludağ Basımevi.

Baum, J.A.C. and Haveman, H. A. (1997). Love thy neighbor? Differentiation and Agglomeration in the Manhattan Hotel Industry, 1898-1990, Administrative Science Quarterly 42 (2), 304-338.

Canina, L., Enz, C. A. and Harrison, J. S. (2005). Agglomeration effects and strategic orientations: Evidence from the U.S. Lodging Industry. Academy of Management Journal, 48, 565-581.

Chou T., Hsu C. and Chen, M. (2008). A Fuzzy Multi-Criteria Decision Model for International Tourist Hotels Location Selection. International Journal of Hospitality Management 27(2), 293-301.

Egan, D. J. and Nield, K. (2000). Towards a theory of intraurban hotel location, Urban Studies, 37(3), 611-622.

Gray, W. S. and Liguari, P. C. (2003). Hotel and Motel Management and Operations. (4 ${ }^{\text {th }}$ ed.) New Jersey: Prentice-Hall.

Kahraman, N. (1986). Turizmde Yatırım Projesi. ( $1^{\text {st }}$ ed.) İstanbul:Çağlayan Kitabevi.

Köseoğlu, F.G. and Baycan, T. (2020). Kentsel Dönüşüm ve Haliç'te Kültür Endüstlerinin Kümelenme Eğilimi. Baycan, T., Deniz, P., Doğruel, F. and Tekçe, M. (Ed), In Kentsel ve Bölgesel Gelişme Dinamikleri ve Mekansal Yansımaları (123-146). İstanbul: Nobel Yayıncılık.

Krugman, P.R. (1991). Increasing Returns and Economic Geography. Journal of Political Economy, 99, 483499.

Law, C.M. (1993). Urban Tourism: Attracting Visitors to Large Cities. London:Mansell.

Nachum, L. (1999). FDI The Location Advantages of Countries and the Competitiveness of TNCs:US FDI in Proffesional Service Industries. Cambridge: University of Cambridge.

Newell, G. and Seabrook, R. (2006). Factors Influencing Hotel Investment Decision Making. Journal of

Property Investment and Finance, 24(4), 279-294.

Olalı, H. and Korzay, M. (1993). Otel İşletmeciliği. (2 $2^{\text {nd }}$ ed.) İstanbul: Beta Yayın Dağıtım.

Rigal-I-Torrent, R. and Fluvia, M. (2011). Managing Tourism Products and Destinations Embedding Public Good Components: A Hedonic Approach, Tourism Management, 32(2), 244-255.

Urtasun, A. and Gutierrez, I. (2006). Hotel Location in Tourism Cities: Madrid 1936-1998, Annals of Tourism Research, 33(2), 382-402.

Yang, Y., Luo, H. and Law, R. (2014). Theoretical, Empirical, and Operational Models in Hotel Location Research, International Journal of Hospitality Management,36, 209-220.

Yang, Y., Wong, K. and Wang, T. (2012). How Do Hotels Choose Their Location? Evidence from Hotels in Beijing. International Journal of Hospitality Management, 31, 675-685.

Yokeno, N., (1968). La localisation de I' Industrie Touristique: Application de I'analyse de Thunen-Weber, Cahiers du Tourisme, Aix-en-Provence: Centre d'études du Tourisme. 
Zhang, H., Guillet, B. and Gao, W. (2012). What Determines Multinational Hotel Groups' Locational Investment Choice in China?, International Journal of Hospitality Management, 31, 350-359.

URL 1, www.terasotel.com

URL 2, www.lazzoni.com

URL 3, www.hilton.com.tr

URL 4, www.clariongoldenhorn.com

Page 43

\section{Resume}

Fatma Gözde Köseoğlu studied City and Regional Planning in Mimar Sinan Fine Arts University. After barchelor education, attended master degree in Regional Planning Programme in Istanbul Technical Üniversity. She completed Realestate Development and Management Doctoral Programme in Ankara University. She conducts researches on urban land rent, urban regeneration, gentrification and clustering.

Tüzin Baycan is Professor of Urban and Regional Planning at Istanbul Technical University. She is Fellow of the Academia Europaea, President of Turkish Regional Science Association and Council Member of European Regional Science Association (ERSA). She is Associate Editor of Asia and Pacific Journal of Regional Science; and Editorial/Advisory Board Member of Regional Science Policy and Practice; Economic and Social Changes: Facts, Trends, Forecast; Social Value \& Intangibles Review; Region; Journal of Independent Studies and Research-Management: Social Sciences and Economics; Romanian Journal of Regional Science; and Studies in Regional Science. She is Co-editor of Resilience, Crisis and Innovation Dynamics (2018); Editor of Knowledge Commercialization and Valorization in Regional Economic Development (2013) and Co-editor of Sustainable City and Creativity: Promoting Creative Urban Initiatives (2011) and Classics in Planning: Urban Planning (2008). Prof. Baycan is the author of many scientific papers and book chapters. Her main research interests cover urban and regional development and planning; urban systems; environment; sustainable development; creativity, innovation and entrepreneurship; diversity and multiculturalism. 